\title{
Increased Risks of Waterborne Disease Outbreaks in Northern Ontario due to Climate Change
}

\author{
Yi Wang, ${ }^{1}$ Edward A. McBean ${ }^{2}$ and Bahram Gharabaghi ${ }^{2}$ \\ ${ }^{1} G H D$, Waterloo, Ontario; ${ }^{2}$ University of Guelph, Guelph, Ontario.
}

\begin{abstract}
Drinking water advisories (DWAs) are issued when source water turbidity is high, because of concern for waterborne disease outbreaks. Small drinking water treatment systems (SDWTS) for First Nations communities in northern regions in Ontario that rely primarily on surface water sources are at risk during heavy storm events due to erosion in the catchment area which causes poor intake water quality to the SDWTS. This study presents a novel method for assessing the potential contribution of climate change to an increased risk of DWAs being issued for rural communities. Trend analysis using rainfall records at three climate stations located in Northern Ontario shows increasing trends of annual maximum five-day cumulative rainfall amounts over the last 3 decades. The $1 \mathrm{~d}$ cumulative rainfall amounts for events occurring 2 times/y on average indicate statistically significant increasing trends of heavy rainfall events, and therefore potentially higher risks of waterborne disease outbreaks.
\end{abstract}

\section{Introduction}

\subsection{Drinking Water Safety in First Nations Com- munities in Northern Ontario}

Ontario is home to 121 First Nations communities with water and wastewater assets (Neegan Burnside 2011), many of which are exposed to health risks due to drinking water vulnerability (Patrick 2011). As of 2016-05-31, there are 126 drinking water advisories (DWAs) in effect in 84 First Nations communities Canada-wide (excluding British Columbia), amongst which 40 communities with 69 DWAs are located in Northern Ontario (Health Canada, Drinking Water Advisories in First Nations Communities, accessed July, 2016).

Drinking water advisories are preventive measures issued when a potential drinking water quality problem has been identified in a community (e.g. Angulo et al. 1997; Wallis et al. 2001). Health Canada utilizes three types of DWAs: Boil Water advisory, Do Not Consume advisory, and Do Not Use advisory. Boil Water advisories are the most commonly used advisory as a precaution against, or in response to, a waterborne disease outbreak (Health Canada 2015). Do Not Consume and Do Not Use advisories are issued when chemical pollutants are identified (Health Canada 2009).

In Ontario, high levels of turbidity or high particle counts are one of the top reasons for issuing DWAs, and 78\% of DWAs were issued to water systems that used surface water as their water sources between 2004 and 2013 (Galway 2016). In addition, of the 158 drinking water systems serving First Nations communities in Ontario, 94 systems are surface water systems and another
13 systems are known to be GUDI (groundwater under the direct influence of surface water; Neegan Burnside 2011). Urgent attention is required to protect First Nations communities in Northern Ontario from the potential impacts of drinking water contamination, especially those associated with surface water turbidity. It is important to know whether conditions are likely to become more severe in terms of increased turbidity.

\subsection{Drinking Water Safety and Relationships with Water Turbidity and Weather Events}

Harvey et al. (2015) investigated the key factors that contribute to DWAs in small drinking water systems (SDWTS) in Ontario and highlighted the greater risk for communities that rely on surface water sources as opposed to groundwater sources. Extensive evidence is available that links waterborne disease outbreaks at drinking water systems to water turbidity and heavy rainfall events. Increased water velocity facilitates the transport of pathogens and other contaminants into surface water and drinking water systems (Thomas et al. 2006; Unc and Goss 2003). Increased turbidity allows waterborne pathogens to attach to mobile particles (McGechan and Lewis 2002). Suspended particles in surface water can enshroud waterborne pathogens and decrease chlorination effectiveness (LeChevallier et al. 1981). Suspended particles can also absorb heat from atmospheric radiation and subsequently increase water temperature and decrease concentrations of dissolved oxygen, resulting in a deterioration of water quality (Yang et al. 2014).

The Walkerton E. Coli outbreak in May 2000 was preceded by a 60 y rainfall event $(5 \mathrm{~d}$ accumulated rainfall amount on

Wang, Yi, Edward A. McBean and Bahram Gharabaghi. 2018. Increased Risks of Waterborne Disease Outbreaks in Northern Ontario due to Climate Change. Journal of Water Management Modeling 26:C436. https://doi.org/10.14796/JWMM.C436 @ CHI 2018. www.chijournal.org ISSN 2292-6062. 
average), and a $100 \mathrm{y}$ event in the heaviest rainfall area, to the south of Walkerton (Auld et al. 2004). Source water turbidity has been associated with acute gastrointestinal illness in Quebec City, Quebec (Gilbert et al. 2006), in Boston, Massachusetts (Beaudeau et al. 2014) and in Milwaukee County, Wisconsin (Morris et al. 1996). Schuster et al. (2005) analyzed drinking-water related waterborne outbreaks in Canada from 1974 through 2001, and suggested a seasonal pattern to outbreaks, with peaks in spring and summer. Spring melt induced overland flow events which, together with intense rainfall events after droughts, were utilized to explain the seasonal increase of illness. Charron et al. (2004) listed extreme precipitation, floods, high temperatures and drought as risk factors for waterborne illness in Canada. Thomas et al. (2006) used the data compiled by Schuster et al. (2005) to estimate an increase of $128 \%$ in the probability of outbreaks if the accumulated rainfall fell into the 94th percentile or higher. Charron et al. (2005) found that rainfall characteristics that include the $5 \mathrm{~d}$ cumulative rainfall amount and have maximum $1 \mathrm{~d}$ rainfall intensity are linked to waterborne disease outbreak frequencies. The statistical significance of waterborne disease outbreaks and extreme precipitation was identified by Curriero et al. (2001), who analyzed 548 reported outbreaks in the United States from 1948 to 1994 and found that $51 \%$ of outbreaks were preceded by heavy precipitation events (defined as events above the 90th percentile).

\subsection{Relationship Between Water Turbidity and Heavy Storms-Soil Erosion}

From the above it is clear that intensive rainfall events may affect source water quality through surface erosion (Lee et al. 2016). There are several aspects of soil erosion to consider, including heavy rainfall events after an extended period of drought (Schuster et al. 2005; Charron et al. 2005); surface runoff increasing the deposition of suspended solids and other contaminants (e.g. pesticides or fertilizers) in reservoirs or surface water bodies (Zhou et al. 2015); resuspension of river sediments; the overflow of surface runoff into source water wells (Hrudey et al. 2002); and infiltration into source water wells through shallow aquifers (unconfined systems).

The universal soil loss equation (USLE) introduced by Wischmeier and Smith (1965) estimates the long term average annual soil loss with respect to segments of arable land under various cropping conditions. Wischmeier and Smith (1965) indicated that storm-generated soil losses are directly proportional to the product of total kinetic storm energy and its maximum $30 \mathrm{~min}$ intensity. Toy and Foster (1998) discussed the revised universal soil loss equation (RUSLE) and introduced its use to compute the rainfall-runoff erosivity factor $R$ for ungauged sites as:

$$
R_{\text {new }}=R_{\text {base }}\left(P_{\text {new }} / P_{\text {base }}\right)^{1.75}
$$

where $P_{\text {new }}$ and $P_{\text {base }}$ are the average annual precipitation at the new location and the base level of precipitation, respectively. This equation demonstrates the exponential relationship between increased rainfall intensity and soil loss. Trenouth and Gharabaghi (2015), Liu et al. (2015) and Thompson et al. (2016) developed new event-based soil loss models that accurately predicted the adverse effects of extreme rainfall events on catchment surface runoff water quality. Stang et al. (2016) investigated sediment rating curves using historic streamflow and water quality records in several basins in Ontario and clearly demonstrated that suspended sediment concentrations and turbidity levels increase by orders of magnitude during heavy storm events (Figure 1).

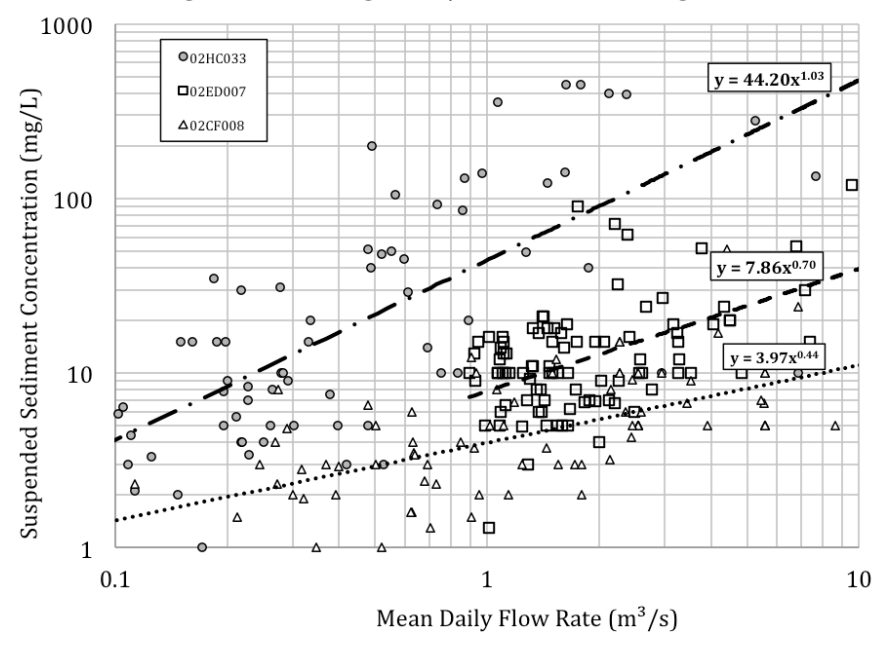

Figure 1 Significant increase in total suspended sediment concentrations during flood flows in selected Ontario streams, including Water Survey of Canada gauges 02HC033, 02ED007 and 02FC008 (Stang et al. 2016).

\subsection{Climate Change and Drinking Water Safety}

Surface water quality and drinking water safety are vulnerable to the effects of climate change, especially elevated temperatures and increased precipitation. Elevated temperatures will increase evaporation, and thus lower water levels and intakes, thus challenging the safety of SDWTS (Crabbé and Robin 2006), reducing groundwater recharge (Rajib et al 2012; Dennis and Dennis 2012), and decreasing annual water availability (Martinez et al. 2015). Heavy rainfall and increases in runoff and erosion will increase the transport of pollutants such as animal feces and pesticides from agricultural land (Delpla et al. 2009; Rajib et al. 2012), and spread waterborne pathogens into receiving surface water bodies (Charron et al. 2004). Increased precipitation can partly explain increases in dissolved organic carbon in North America (Monteith et al. 2007), and it is related to the raw water quality index in both Quebec and Newfoundland and Labrador (Rajib et al. 2012).

The Work Group 1 Fifth Assessment Report (IPCC 2013) noted that changes in daily precipitation extremes are occurring, and that there are strong regional and sub-regional variations. Both increasing and decreasing trends are observed in precipitation extremes. Since the middle of the twentieth century, regional trends that vary between continents have been appearing. They include increasing trends identified in North and South America, 
regional and seasonal variations found in Europe and the Mediterranean, mixed regional trends found in Asia and Oceania, and no significant trends in Africa. Global assessment is currently unavailable for sub-daily trends of precipitation extremes; however, several regions have identified significant trends, and more increasing trends have been observed than have decreasing trends (IPCC 2013, section 2.6.2).

In 2011, the Ontario Centre for Climate Impacts and Adaptation Resources (OCCIAR) conducted workshops in Northern Ontario to discuss local impacts of climate change and adaptation strategies (OCCIAR 2011). The four communities were Hearst, Kapuskasing, Smooth Rock Falls and Cochrane, which are all surrounded by many small communities, including First Nations communities. The communities have experienced various changes in both climate and weather, including warmer temperatures in winter and spring, changes in precipitation, intense storms, and flooding. Some lakes in the area have lower water levels due to warmer spring seasons and changes in precipitation.

\subsection{Study Objectives}

This study aims to provide insights into the implications, for the risk of drinking water advisories being issued, of the increasing trends in the frequency of heavy rainfall events. Of particular interest is whether there are changes in heavy rainfall events or droughts in Northern Ontario which may result in increased frequencies of DWAs being issued. Based on the daily rainfall records at three climate stations in Northern Ontario, this research reports on the statistical significance of changes in several rainfall statistics which are related to drinking water treatment system security. The $5 \mathrm{~d}$ cumulative rainfall amount and maximum $1 \mathrm{~d}$ rainfall amount data were analyzed to identify changes in the rainfall erosivity factor (the rainfall-runoff erosivity factor $R$ in RUSLE, Equation 1). The monthly and the lowest $31 \mathrm{~d}$ accumulated rainfall amounts were also examined to identify changes in drought conditions.

\section{Meteorological Data}

Daily rainfall records for Northern Ontario are available from Environment Canada from as early as the 1960s, perhaps earlier. The climate stations located at Sioux Lookout Airport (Station ID: 6037775) and Sudbury Airport (Station ID: 6068150) both have 52 y of rainfall records, covering 1960 to 2012 (substantial numbers of records were missing for both locations for the year 1993). The climate station at Earlton Airport (Station ID: 6072225) has $45 \mathrm{y}$ of rainfall records. The stations were selected from a limited number of available gauges in Northern Ontario based on the proximity of the station to First Nations communities. Figure 2 shows the locations of the climate stations. The background map, The Ontario First Nations Map, was obtained from https:/www. ontario.ca/page/ontario-first-nations-maps.

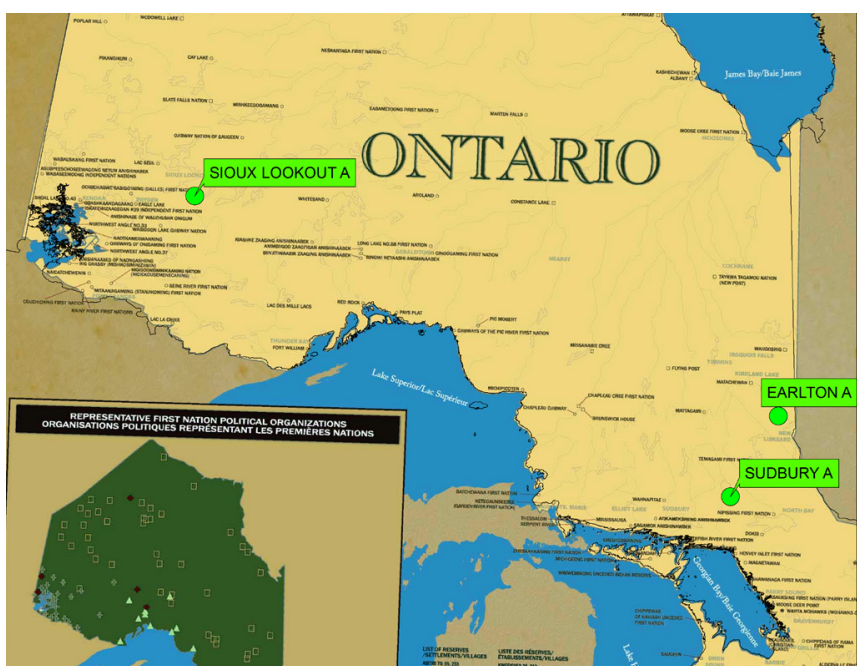

Figure 2 Locations of selected climate stations and First Nations communities in Northern Ontario.

Monthly total rainfall amounts were calculated for June, July and August in each year. A lowest $31 \mathrm{~d}$ rainfall amount was calculated as the minimum consecutive $31 \mathrm{~d}$ total rainfall amount in the period May 1 to September 30. One day and $5 \mathrm{~d}$ cumulative rainfall amounts were calculated year-round and annual maximum series were constructed. The minimum value in the $1 \mathrm{~d}$ annual maximum series was used to extract a $1 \mathrm{~d}$ partial duration series. The rainfall events in the partial duration series were screened to ensure a $24 \mathrm{~h}$ cessation of rainfall between events.

\section{Changes in Rainfall Intensity}

\subsection{Mann-Kendall Trend Test}

The Mann-Kendall trend test was used to test the monotonic trend in the time series $x_{i}$. It compares a standardization of the Kendall $S$ statistic to the normal distribution, and rejects the null hypothesis (no monotonic trend) if $S$ is significantly different from zero.

The test statistic $S$ is calculated as:

$$
S=\sum_{i<k} \operatorname{sign}\left(x_{k}-x_{i}\right)
$$

with

$$
\operatorname{sign}(x)=\left\{\begin{array}{cc}
1 & x>0 \\
0 & x=0 \\
-1 & x<0
\end{array}\right.
$$

For large sample sizes $(n>8), S$ is normally distributed with:

$$
E(S)=0, \operatorname{var}(S) \approx n(n-1)(2 n+5) / 18
$$

where:

$$
\begin{gathered}
E(S)=\text { expected value } \\
\text { var }=\text { variance of } X .
\end{gathered}
$$


The standardized test statistic $Z$ is calculated and compared to the normal distribution.

$$
Z=\left\{\begin{array}{cc}
(S-1) / \sqrt{\operatorname{var}(S)} & S>0 \\
0 & S=0 \\
(S+1) / \sqrt{\operatorname{var}(S)} & S<0
\end{array}\right.
$$

$S$ needs to be corrected if there are ties in $\left\{x_{i}\right\}$, which is very rare if used on the total rainfall amount. The Mann-Kendall trend test was implemented using the R package, R 2013, developed by McLeod (2011).

The Mann-Kendall trend test does not require assumptions of normality between observations, but no serial correlation is allowed. Therefore lag-1 autocorrelation was used to detect serial correlations.

\subsection{Bootstrapping Percentile Estimation}

The bootstrapping method was used to estimate percentiles and related confidence limits. The original data series were resampled with replacement for 1000 samples, and for each resampled dataset the percentile was estimated by interpolating ranked data values which had the closest exceedance probabilities to the given percentile. The non-exceedance probability for the ith largest value was calculated as:

$$
p_{i}=(i-1) /(n-1), i=1, \ldots, n
$$

where $n$ is the sample size. The 1000 resampled estimates were pooled together, the mean value was used as the percentile estimate, and the $5 \%$ and $95 \%$ quantiles were used as the confidence limits of the $90 \%$ confidence level.

\section{Results}

\subsection{Changes in Monthly Total Rainfall Amount and Lowest $31 \mathrm{~d}$ Accumulated Rainfall Amount.}

The total monthly rainfall amounts in June, July and August for Sioux Lookout are shown in Figure $3 a$ as scattered symbols. In Figure $3 a$ the solid black curve represents the lowest monthly total rainfall amount of the three months. These lowest monthly values were further smoothed using local regression (the LOWESS, locally weighted scatterplot smoothing, method; Cleveland 1981) to depict potential trends, and are drawn as the dashed black curve. The lowest $31 \mathrm{~d}$ total rainfall amount is drawn as a solid grey curve, along with the local regression curve which is drawn as a dashed grey curve. Similar figures were created for Sudbury in Figure 3b and for Earlton in Figure 3c.

The Mann-Kendall trend test did not detect any significant monotonic trends in the lowest monthly total rainfall amounts. However, the local regression of the lowest $31 \mathrm{~d}$ accumulated rainfall amounts showed increasing tendencies at all three locations, and the local regression of lowest monthly values showed increasing tendencies at Earlton and Sudbury as well. In
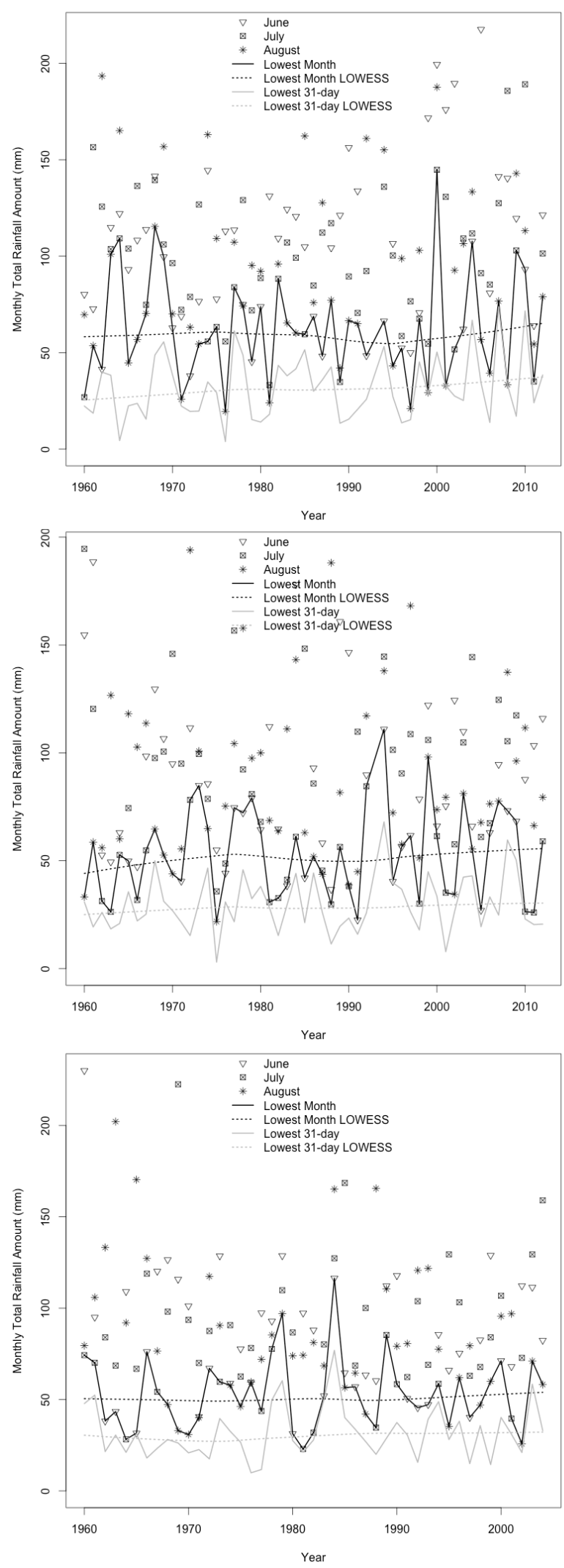

Figure 3 Monthly total rainfall amount in June, July and August for the Sioux Lookout (a, top), Sudbury (b, centre) and Earlton (c, bottom) airport climate stations. 
other words, the drought conditions have improved, though the change is not not statistically significant. Moreover, if the current lowest $31 \mathrm{~d}$ total rainfall is considered to be a drought at these locations, then it is possible that this drought situation will continue in the near future.

\subsection{Five Day Cumulative Rainfall.}

The $5 \mathrm{~d}$ cumulative rainfall annual maximum series at Sioux Lookout are shown in Figure 4a, together with the local regression curve (LOWESS). The LOWESS of annual maximum data series shows an obvious decreasing trend until 1980, and an increasing trend thereafter. The $93 \mathrm{rd}$ percentile estimates and corresponding $90 \%$ confidence limits are drawn in Figure 4 a as well. The width of the moving window was selected as 15 y $\left(\frac{1}{1-0.93}=14.3 \approx 15\right)$ to reduce uncertainties involved in the percentile estimates. The decreasing trend before 1974 is mainly attributed to the peak event in 1966 (a total of $144.8 \mathrm{~mm}$ ), and the increasing trend after that is clearly evident. Similar figures were created for Sudbury (Figure 4c) and for Earlton (Figure 4b).

The trends of annual maximum $5 \mathrm{~d}$ cumulative rainfall at Earlton (Figure 4b) show a pattern similar to the trends for Sioux Lookout. The annual maximum data series started to increase before 1980, and the 93rd percentile started to increase from the mid-1980s. On the other hand, rainfall records at Sudbury (Figure 4c) showed stationarity in annual maximum data series, and a dominant decreasing trend in the 93rd percentiles.

\subsection{One Day Cumulative Rainfall Amount}

The $1 \mathrm{~d}$ cumulative rainfall amount was extracted as a partial duration series, in addition to annual maximum series, to estimate events having return periods $<1 \mathrm{y}$. The threshold value used to construct the partial duration series was the minimum value from the annual maximum series. Events having a recurrence frequency of 2 times/y were estimated, with $90 \%$ confidence limits, for a moving window of $10 \mathrm{y}$.

Figure 5a (below) shows the partial duration series at Sioux Lookout as scattered points and its local regression as a dashed curve. The estimate of the 2 times/y event and $90 \%$ confidence limits were calculated and are also drawn in Figure $5 a$. The estimates of the 2-times/y event increased significantly from barely $>20 \mathrm{~mm}$ in the late 1970 s to almost $40 \mathrm{~mm}$ in the late $2000 \mathrm{~s}$. A statistically significant increasing trend was also observed in 2 times/y events estimated from the Earlton rainfall records (Figure 5b); however, estimates based on Sudbury rainfall records did not show any significant trends (Figure $5 c$ ).

\section{Discussion}

The Mann-Kendall trend test did not detect any statistically significant trends in monthly total rainfall and minimum $31 \mathrm{~d}$ total rainfall in summer, which indicates that if the summer droughts in the past several decades were causing substantial soil erosion and subsequently increasing the risks of waterborne disease out-
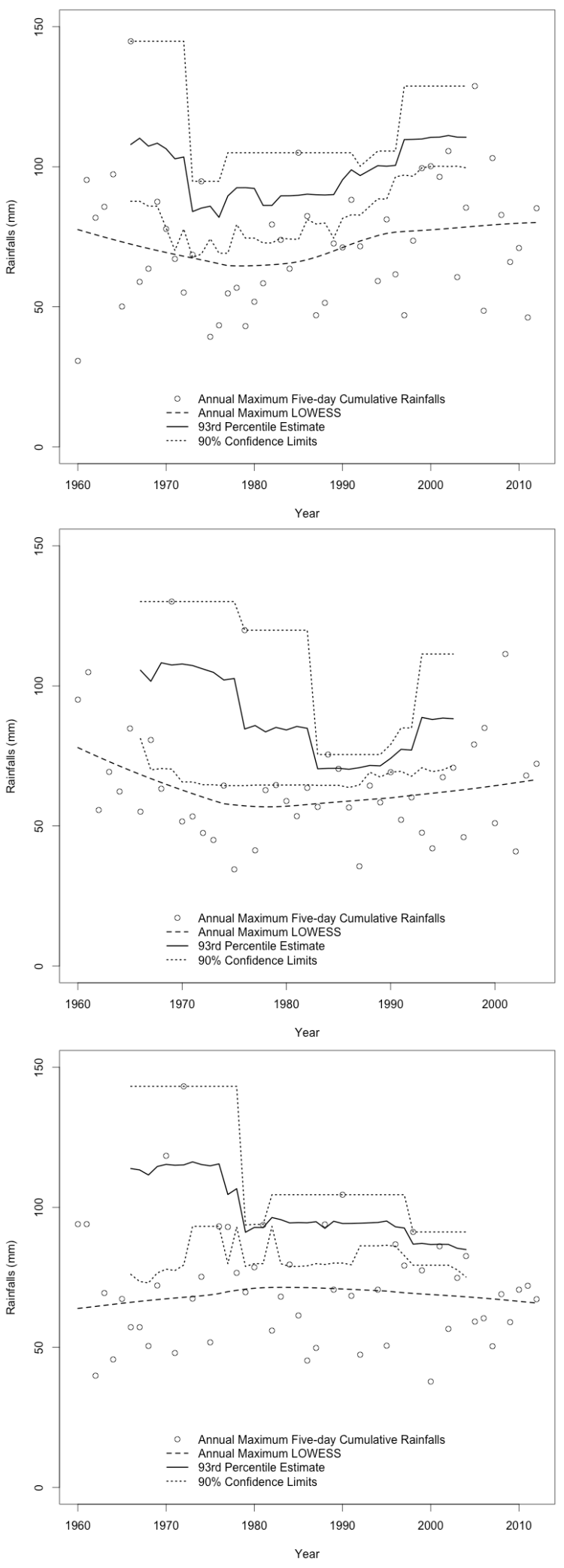

Figure 4 Annual maximum data series and 93rd percentile estimates of the $5 \mathrm{~d}$ cumulative rainfall amount, with $15 \mathrm{y}$ moving window, at Sioux Lookout (a, top), Earlton (b, centre) and Sudbury (c, bottom) airports. 

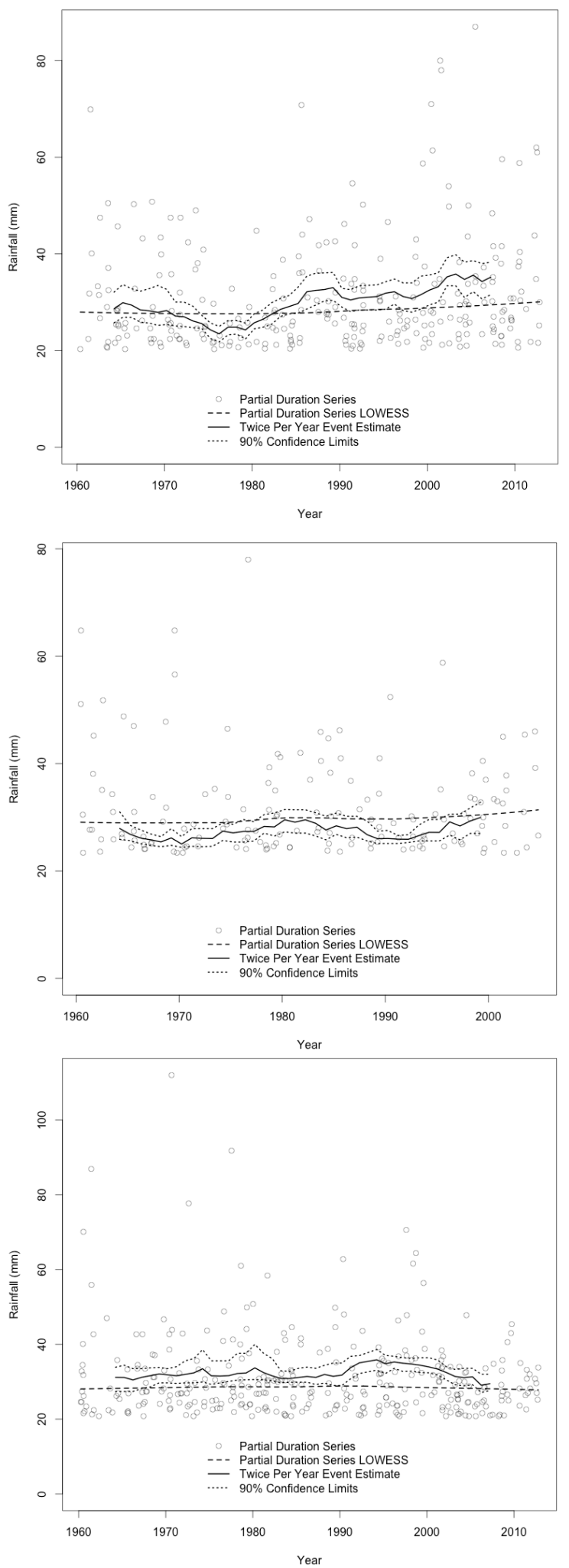

Figure 5 The partial duration series of the rainfall records at Sioux Lookout (a, top), Earlton (b, centre) and Sudbury (c, bottom) airports, and the estimate and confidence limits of events occurring 2 times/y on average, using moving window of $10 \mathrm{y}$ rainfall record. breaks, then these types of risks will probably continue to exist in the near future. Thus the protection of drinking water treatment systems against drought conditions should be continued as well. This conclusion should be applicable to most First Nations communities in Northern Ontario since rainfall records from the three climate stations all show similar stationarity in summer droughts.

The increasing trends started in the 1980s, detected in both the annual maximum data series and the 93rd percentiles of $5 \mathrm{~d}$ cumulative rainfall, should raise awareness in relation to pollution control and source water protection. The $5 \mathrm{~d}$ cumulative rainfall amount has proven to be a critical indicator of waterborne disease outbreaks, and a predictable increase in $5 \mathrm{~d}$ cumulative rainfall will definitely raise the risk of waterborne disease outbreaks. The increasing $1 \mathrm{~d}$ cumulative rainfall amount indicates the necessity of protecting surface water sources from surface runoff pollution, and of protecting groundwater sources from the direct influence of surface water.

Spatial variation amongst the three climate stations was observed in the trends that were detected. In general, Sioux Lookout and Earlton have experienced increases in both the amount and the frequency of heavy rainfall events, while Sudbury has shown more stationarity. Considering that Sudbury is the southernmost station of the three, it is reasonable to predict that First Nations communities located in the far north will experience more changes in heavy rainfall events, and eventually more challenges in providing adequate drinking water treatment.

The results presented in this study, in general, are in agreement with recent climate change studies in Ontario (Asnaashari et al. 2015; Rudra et al. 2015; Vasiljevic et al. 2012).

\section{Conclusions}

This study presents a novel method for assessing increased risks of waterborne disease outbreaks in rural Northern Ontario communities due to climate change. This study shows that the changes in the frequency of the occurrence of heavy rainfall events, which cause poor water quality in the SDWTS intakes and overwhelm them, can increase the risk of waterborne disease outbreaks. The heavy rainfall event statistics are highly related to intake water quality for small rural communities in Northern Ontario and thus the increased risk of waterborne disease outbreaks in these communities. This emerging concern demands more awareness and proper investment to mitigate the risks.

\section{Acknowledgments}

The research fund provided by NSERC-NCE Res'Eau for small drinking water systems is appreciated, and the data provided by Environment Canada is acknowledged.

\section{References}

Angulo, F. J., S. Tippen, D. J. Sharp, B. J. Payne, C. Collier, J. E. Hill, T. J. Barrett, R. M. Clark, E. E. Geldreich, H. D. Donnell Jr and D. 
L. Swerdlow. 1997. "A Community Waterborne Outbreak of Salmonellosis and the Effectiveness of a Boil Water Order." American Journal of Public Health 87 (4): 580-4.

Asnaashari, A., B. Gharabaghi, E. McBean and A. A. Mahboubi. 2015. "Reservoir Management Under Predictable Climate Variability and Change." Journal of Water and Climate Change 6 (3): 472-85.

Auld, H., D. Maclver and J. Klaassen. 2004. "Heavy Rainfall and Waterborne Disease Outbreaks: The Walkerton Example." Journal of Toxicology and Environmental Health, Part A 67 (20): 1879-87.

Beaudeau, P., J. Schwartz and R. Levin. 2014. Drinking Water Quality and Hospital Admissions of Elderly People for Gastrointestinal Illness in Eastern Massachusetts, 1998-2008. Water Research 52 (1): 188-98. https://doi.org/10.1016/j.watres.2014.01.005

Charron, D., T, Edge, M. Fleury, W. Galatianos, D. Gillis, R. Kent, A. Maarouf, C. Neudoerffer, C. Schuster, M. Thomas, J. Valcour and D. Waltner-Toews. 2005. Links Between Climate, Water and Waterborne IIIness, and Projected Impacts of Climate Change_Final Technical Report to HPRP. Ottawa: Health Canada.

Charron, D. F., M. K. Thomas, D. Waltner-Toews, J. J. Aramini, T. Edge, R. A. Kent, A. R. Maarouf and J. Wilson. 2004. “Vulnerability of Waterborne Diseases to Climate Change in Canada: A Review." Journal of Toxicology and Environmental Health, Part A 67 (20): 1667-77.

Cleveland, W. S. 1981. "LOWESS: A Program for Smoothing Scatterplots by Robust Locally Weighted Regression." The American Statistician 35 (1): 54.

Crabbé, P. and M. Robin. 2006. “Institutional Adaptation of Water Resource Infrastructures to Climate Change in Eastern Ontario." Climatic Change 78 (1):103-33. https://doi.org/10.1007/s10584-006-9087-5

Curriero, F. C., J. A. Patz, J. B. Rose and S. Lele. 2001. "The Association Between Extreme Precipitation and Waterborne Disease Outbreaks in the United States, 1948-1994." American Journal of Public Health 91(8): 1194-9.

Delpla, I., A.-V. Jung, E. Baures, M. Clement and O. Thomas. 2009. "Impacts of Climate Change on Surface Water Quality in Relation to Drinking Water Production." Environment International 35 (8): 1225-33.

Dennis, I. and R. Dennis. 2012. Climate Change Vulnerability Index for South African Aquifers. Water SA 38 (3): 417-26.

Galway, L. P. 2016. “Boiling Over: A Descriptive Analysis of Drinking Water Advisories in First Nations Communities in Ontario, Canada." International Journal of Environmental Research and Public Health 13 (5): 505. https://doi.org/10.3390/ijerph13050505

Gilbert, M.-L., P. Levallois and M. J. Rodriguez. 2006. “Use of a Health Information Telephone Line, Info-santé CLSC, for the Surveillance of Waterborne Gastroenteritis." Journal of Water and Health 4 (2): 225-32.

Harvey, R., H. M. Murphy, E. A. McBean and B. Gharabaghi. 2015. "Using Data Mining to Understand Drinking Water Advisories in Small Water Systems: A Case Study of Ontario First Nations Drinking Water Supplies." Water Resources Management 29 (14): 5129-5139.

Health Canada. 2009. Drinking Water Advisories in First Nations Communities in Canada: A National Overview. Ottawa: Health Canada.

Health Canada. 2015. Guidance for Issuing and Rescinding Boil Water Advisories in Canadian Drinking Water Supplies. Ottawa: Health Canada. Water and Air Quality Bureau, Healthy Environments and Consumer Safety Branch.

Hrudey, S. E., P. M. Huck, P. Payment, R. W. Gillham and E. J. Hrudey. 2002. "Walkerton: Lessons Learned in Comparison with Waterborne Outbreaks in the Developed World." Journal of Environmental Engineering and Science 1 (6): 397-407.

IPCC. 2013. Climate Change 2013: The Physical Science Basis. Contribution of Working Group I to the Fifth Assessment Report of the Intergovernmental Panel on Climate Change, edited by T. F. Stocker, D. Qin, G.-K. Plattner, M. Tignor, S. K. Allen, J. Boschung, A. Nauels, Y. Xia, V. Bex and P. M. Midgley. Cambridge: Cambridge University Press. https://doi.org/10.1017/CBO9781107415324

LeChevallier, M. W., T. M. Evans and R. J. Seidler. 1981. “Effect of Turbidity on Chlorination Efficiency and Bacterial Persistence in Drinking Water." Applied and Environmental Microbiology 42 (1): 159-67.

Lee, C.-S., Y.-C. Lee and H.-M. Chiang. 2016. "Abrupt State Change of River Water Quality (Turbidity): Effect of Extreme Rainfalls and Typhoons." Science of The Total Environment (557-558):91-101. https://doi.org/10.1016/j.scitotenv.2016.02.213

Liu, Y., W. Yang, Z. Yu, I. Lung and B. Gharabaghi. 2015. “Estimating Sediment Yield from Upland and Channel Erosion at a Watershed Scale Using SWAT." Water Resources Management 29 (5): 1399-1412.

Martinez, S., S. Kralisch, O. Escolero and M. Perevochtchikova. 2015. "Vulnerability of Mexico City's Water Supply Sources in the Context of Climate Change." Journal of Water and Climate Change 6 (3): 518-33. https://doi.org/10.2166/wcc.2015.083

McGechan, M. and G. Lewis. 2002. “Transport of Particulate and Colloid-Sorbed Contaminants Through Soil, Part 1: General Principles." Biosystems Engineering 83 (3): 255-73.

McLeod, A. 2011. Kendall: Kendall Rank Correlation and MannKendall Trend Test (R package version 2.2). Vienna: The $\mathrm{R}$ Foundation. https://cran.r-project.org/web/packages/Kendall/Kendall. pdf 
Monteith, D. T., J. L. Stoddard, C. D. Evans, H. A. de Wit, M. Forsius, T. Hogasen, A. Wilander, B. L. Skjelkvale, D. S. Jeffries, J. Vuorenmaa, B. Keller, J. Kopacek and J. Vesely. 2007. “Dissolved Organic Carbon Trends Resulting from Changes in Atmospheric Deposition Chemistry." Nature 450 (7169): 537-40.

Morris, R. D., E. N. Naumova, R. Levin and R. L. Munasinghe. 1996. "Temporal Variation in Drinking Water Turbidity and Diagnosed Gastroenteritis in Milwaukee." American Journal of Public Health 86 (2): 237-9.

Neegan Burnside. 2011. National Assessment of First Nations Water and Wastewater Systems-Ontario Regional Roll-up Report. Ottawa: Department of Indian and Northern Affairs Canada.

OCCIAR (Ontario Centre for Climate Impacts and Adaptation Resources). 2011. Climate Change Impacts and Adaptation in Northern Ontario-Workshop Report. Sudbury, Ontario: Ontario Centre for Climate Impacts and Adaptation Resources.

Patrick, R. J. 2011. “Uneven Access to Safe Drinking Water for First Nations in Canada: Connecting Health and Place Through Source Water Protection." Health and Place 17 (1): 386-9.

R Core Team. 2013. R: A Language and Environment for Statistical Computing. Vienna: The R Foundation. https://cran.r-project.org/doc/manuals/r-release/fullrefman.pdf

Rajib, M. A., M. M. Rahman and E. A. McBean. 2012. “Evaluating Technological Resilience of Small Drinking Water Systems Under the Projected Changes of Climate." Journal of Water and Climate Change 3 (2): 110-24.

Rudra, R. P., W. T. Dickinson, S. I. Ahmed, I. Patel, J. Zhou, B. Gharabaghi and A. A. Khan. 2015. “Changes in Rainfall Extremes in Ontario." International Journal of Environmental Research 9 (4): 1117-26.

Schuster, C., A. Ellis, W. Robertson, D. Charron, J. Aramini, B. Marshall and D. Medeiros. 2005. "Infectious Disease Outbreaks Related to Drinking Water in Canada." Canadian Journal of Public Health 96 (4): 254-8.

Stang, C., B. Gharabaghi, R. Rudra, G. Golmohammadi, A. Mahboubi and S. Ahmed. 2016. “Conservation Management Practices: Success Story of the Hog Creek and Sturgeon River Watersheds, Ontario, Canada." Journal of Soil and Water Conservation 71 (3): 237-48.
Thomas, K. M., D. F. Charron, D. Waltner-Toews, C. Schuster, A. R. Maarouf and J. D. Holt. 2006. "A Role of High Impact Weather Events in Waterborne Disease Outbreaks in Canada, 1975-2001." International Journal of Environmental Health Research 16 (3): 167-80.

Thompson, J., A. M. Sattar, B. Gharabaghi and R. C. Warner. 2016. "Event-Based Total Suspended Sediment Particle Size Distribution Model." Journal of Hydrology 536:236-46.

Toy, T. J. and G. R. Foster. 1998. Guidelines for the Use of the Revised Universal Soil Loss Equation (RUSLE) on Mined Lands, Construction Sites, and Reclaimed Lands. Denver, CO: The Office of Technology Transfer Western Regional Coordinating Center, Office of Surface Mining.

Trenouth, W. R. and B. Gharabaghi. 2015. "Event-Based Soil Loss Models for Construction Sites." Journal of Hydrology 524:780-8.

Unc, A. and M. Goss. 2003. "Movement of Faecal Bacteria through the Vadose Zone." Water, Air, and Soil Pollution 149 (1): 327-37.

Vasiljevic, B., E. A. McBean and B. Gharabaghi. 2012. "Trends in Rainfall Intensity for Stormwater Designs in Ontario." Journal of Water and Climate Change 3 (1): 1-10.

Wallis, P. M., D. Matson, M. Jones and J. Jamieson. 2001. "Application of Monitoring Data for Giardia and Cryptosporidium to Boil Water Advisories." Risk Analysis 21 (6): 1077-85.

Wischmeier, W. H. and D. D. Smith. 1965. Predicting Rainfall-Erosion Losses from Cropland East of the Rocky Mountains: Guide for Selection of Practices for Soil and Water Conservation. Washington, DC: U.S. Department of Agriculture, Agricultural Research Service. Agriculture Handbook No. 282. https://naldc.nal.usda.gov/download/CAT87208342/PDF

Yang, T.-M., S.-K. Fan, C. Fan and N.-S. Hsu. 2014. “Establishment of Turbidity Forecasting Model and Early-Warning System for Source Water Turbidity Management Using Back-Propagation Artificial Neural Network Algorithm and Probability Analysis." Environmental Monitoring and Assessment 186 (8): 4925-34.

Zhou, Z. Z., T. L. Huang, W. X. Ma, Y. Li and Z. Kang. 2015. “Impacts of Water Quality Variation and Rainfall Runoff on Jinpen Reservoir, in Northwest China." Water Science and Engineering 8 (4): 301-8. 